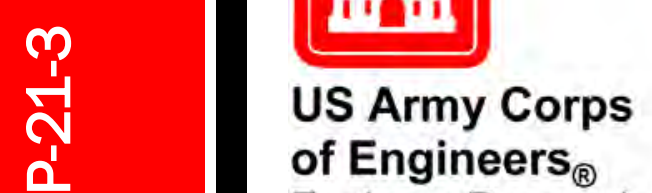

Engineer Research and

Development Center

\title{
Crevice Corrosion and Environmentally Assisted Cracking of High-Strength Duplex Stainless Steels in Simulated Concrete Pore Solutions
}

Robert D. Moser, Preet M. Singh, Lawrence F. Kahn,

August 2021

Kimberly E. Kurtis, David González Niño, and

Zackery B. McClelland 
The U.S. Army Engineer Research and Development Center (ERDC) solves the nation's toughest engineering and environmental challenges. ERDC develops innovative solutions in civil and military engineering, geospatial sciences, water resources, and environmental sciences for the Army, the Department of Defense, civilian agencies, and our nation's public good. Find out more at www.erdc.usace.army.mil.

To search for other technical reports published by ERDC, visit the ERDC online library at https://erdclibrary.on.worldcat.org/discovery. 


\section{Crevice Corrosion and Environmentally Assisted Cracking of High-Strength Duplex Stainless Steels in Simulated Concrete Pore Solutions}

Robert D. Moser and Zackery B. McClelland

Geotechnical and Structures Laboratory

U.S. Army Engineer Research and Development Center 3909 Halls Ferry Road

Vicksburg, MS 39180

Preet M. Singh, Lawrence F. Kahn, and Kimberly E. Kurtis

School of Materials Science \& Engineering /School of Civil \& Environmental Engineering Georgia Institute of Technology

North Ave NW

Atlanta, GA 30332

David González Niño

Department of Civil Engineering

University of Arkansas

Fayetteville, AR 72701

Final report

Approved for public release; distribution is unlimited.

Prepared for U.S. Army Corps of Engineers

Washington, DC 20134

Under GDOT Project Number 07-70 and Army Environmental Quality and Installations Basic Research Program 


\section{Preface}

This study was conducted for the U.S. Army Corps of Engineers under the Army's Environmental Quality and Installations Basic Research Program and Georgia Department of Transportation (GDOT) Project Number 0770 .

The work was performed by the U.S. Army Engineer Research and Development Center, Geotechnical and Structures Laboratory (ERDC-GSL). At the time of publication of this paper, the Deputy Director of ERDC-GSL was Mr. Charles W. Ertle II was Deputy Director of ERDC-GSL, and the Director was Mr. Bartley P. Durst.

Sumiden Wire Products Corporation and Fagersta Stainless are thanked for their donation of materials and all technical assistance provided. The authors would also like to thank Mr. Daniel Schuetz for assistance with the production of test specimens and metallographic sample preparation and Mr. J amshad Mahmood for help with fabricating experimental setups.

The Commander of ERDC was COL Teresa A. Schlosser and the Director was Dr. David W. Pittman.

DISCLAIMER: The contents of this report are not to be used for advertising, publication, or promotional purposes. Citation of trade names does not constitute an official endorsement or approval of the use of such commercial products. All product names and trademarks cited are the property of their respective owners. The findings of this report are not to be construed as an official Department of the Army position unless so designated by other authorized documents. 


\title{
Crevice corrosion and environmentally assisted cracking of high-strength duplex stainless steels in simulated concrete pore solutions
}

\begin{abstract}
A B S T R A C T
This paper presents a study of crevice corrosion and environmentally assisted cracking (EAC) mechanisms in UNS S32205 and S32304 which were cold drawn to tensile strengths of approximately $1300 \mathrm{MPa}$. The study utilized a combination of electrochemical methods and slow strain rate testing to evaluate EAC susceptibility. UNS S32205 was not susceptible to crevice corrosion in stranded geometries at $\mathrm{Cl}^{-}$concentrations up to $1.0 \mathrm{M}$ in alkaline and carbonated simulated concrete pore solutions. UNS S32304 did exhibit a reduction in corrosion resistance when tested in a stranded geometry. UNS S32205 and S32304 were not susceptible to stress corrosion cracking at $\mathrm{Cl}^{-}$concentrations up to $0.5 \mathrm{M}$ in alkaline and carbonated solutions but were susceptible to hydrogen embrittlement with cathodic overprotection.
\end{abstract}

\section{Introduction}

Corrosion of embedded reinforcing steels is a prevalent issue in concrete structures exposed to marine environments and deicing chemicals, e.g., $\mathrm{NaCl}$ and $\mathrm{CaCl}_{2}$. These environmental exposures contribute chlorides $\left(\mathrm{Cl}^{-}\right)$that can ingress and ultimately destabilized passive films formed on the surface of steel reinforcing bars, leading to corrosion [1]. While many strategies are available to mitigate corrosion; including the use of high-performance/low permeability concretes, increased cover thicknesses, and coatings, these technologies often cannot provide necessary corrosion resistance as the service lives of critical concrete structures (e.g., bridges, dams, ports, etc.) are extended beyond 75 years [2]. As a result, materials with intrinsic corrosion resistant properties, such as stainless steel reinforcement, must be investigated.

The use of various stainless steel alloys for corrosion-resistant reinforcement has been the subject of much research, with a focus primarily on austenitic grades (e.g., UNS S30400 and S31600) and, more recently, on austentic-ferritic duplex grades (e.g., UNS S32101, S32205, and S32304) [3-10]. These materials have generally been shown to exhibit excellent corrosion resistance when compared with mild steel reinforcement, with an increase in chloride threshold levels (CTLs; i.e., the chloride concentration necessary for corrosion initiation) of approximately one order of magnitude $[11,12]$.

However, there has been significantly less study of highstrength corrosion-resistant reinforcing materials for use in prestressed concrete applications. Prestressed concrete is often used in construction to minimize tensile cracking of the concrete by "prestressing" the steel reinforcement in tension to apply a 
"precompressive" stress to the concrete that is strong in compression [13]. This precompression of the concrete allows for longer spans and improved durability and has become a ubiquitous form of concrete construction in bridges, parking decks, piling, and other structures. As a result, many additional requirements are placed on the mechanical properties of the reinforcement:

- Ultimate tensile strengths on the order of $1900 \mathrm{MPa}$ compared with $500 \mathrm{MPa}$ for mild steel reinforcement.

- Stress relaxation of less than $2.5 \%$ when loaded to $70 \%$ of the ultimate tensile strength for a period of $1000 \mathrm{~h}$.

- 7-wire strands produced continuously in a roll which provides for curved as well as straight placement in a structure with no discontinuities in the prestressing forces applied to the concrete.

These rigorous mechanical requirements place many additional constraints on which corrosion-resistant alloys can be used for prestressing reinforcement and how they can be produced (e.g., thermomechanical heat treatments). The fact that prestressing reinforcements are produced in a stranded geometry also causes concerns for the influence of crevice corrosion phenomena [14]. The authors recently demonstrated this effect in stranded pearlitic prestressing steels, where a reduction in CTLs of approximately $70 \%$ was attributed to stranding and associated crevice corrosion [15]. In addition, the constant tensile stress state of approximately $70 \%$ of the material's ultimate strength presents concerns for environmentally assisted cracking (EAC) mechanisms, such as stress corrosion cracking (SCC) and hydrogen embrittlement (HE), that have been previously reported [16-22].

Corrosion-resistant high-strength stainless steels for prestressing applications have been the subject of recent research and field application, with a focus on a variety of alloys. Initial research of these materials concentrated on high-strength nitrogen-charged austenitic alloys with a goal of achieving strengths similar to those of high-C prestressing steels, high corrosion resistance, and low magnetic permeability [23]. Work performed under COST Action 534 - New Materials and Systems in PSC Structures, an effort supported by the European Union [24-30], investigated high-strength stainless steels produced from alloys UNS S30400, and S31600 which were cold drawn to achieve tensile strengths required for prestressing applications. These studies investigated resistance to $\mathrm{Cl}^{-}$induced corrosion and EAC mechanisms.

The authors' prior publication presented the results of a comprehensive study of the $\mathrm{Cl}^{-}$induced corrosion resistance of highstrength stainless steels (tensile strengths of 1300-1800 MPa) in simulated alkaline $(\mathrm{pH} \sim 12.5)$ and carbonated $(\mathrm{pH} \sim 9)$ concrete pore solutions [31]. The study included austenitic grades UNS S30400 and S31600; duplex grades S32101, S32205, and S32304;

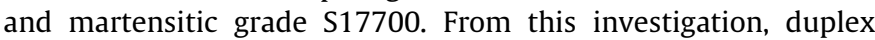
grades UNS S32205 and S32304 were identified to be the best performing, with no corrosion evidenced at $\mathrm{Cl}^{-}$concentrations of up to $0.5 \mathrm{~mol} / \mathrm{L}$ in alkaline and carbonated solutions.

Studies of EAC mechanisms in stainless steels have largely focused on austenitic allows such as UNS S30400 and S31600 without strengthening along with limited recent study of advanced steel alloys including corrosion-resistant duplex stainless steels
[32-36]. The effect of heat treatment on the hydrogen embrittlement susceptibility of $17 \% \mathrm{Cr}$ stainless steel was studied by Tavares et al. [37]. Samples, quenched and tempered at different temperatures were subjected to cathodic hydrogen charging in a $3.5 \% \mathrm{NaCal}$ solution for $24 \mathrm{~h}$ prior a slows strain rate test and it was maintained during the SSRT. Samples tempered at $650{ }^{\circ} \mathrm{C}$, which possess a high toughness and low hardness, showed the lowest H.E. susceptibility with a strain reduction of $57 \%$. Samples tempered at $500{ }^{\circ} \mathrm{C}$, which have high hardness and low toughness, exhibited the highest susceptibility with a strain reduction of $86 \%$. HeonYound $\mathrm{Ha}$ et al. [38] performed a study where a correlation between $\mathrm{N}$ content in duplex stainless steel and resistance to corrosion cracking studied using slow strain rate testing (SSRT) methods on two alloys of varying $\mathrm{N}$ content. The alloy with higher $\mathrm{N}$ content had higher resistance to stable pit initiation than its counterpart. Also, the reduction on strain and tensile strength due to stress corrosion cracking was lower in the alloy with higher $\mathrm{N}$ content $(64.3 \%$ compared to $87 \%$ in elongation and $33 \%$ compared to $64 \%$ in strength). A surface examination was performed after the SSRT and it was seen significant amounts of pits in the alloy with lower $\mathrm{N}$ content, which matched with previous observations.

Additional studies focused on microstructural characterization of EAC damage in duplex stainless steels include work by Kheradmand et al. [39] using nano-indentation with an in-situ hydrogen charging on different phases, austenite and ferrite, in a duplex stainless steel UNS S32507. It was found that hardness in both phases, austenite and ferrite, increases with electrochemically charged hydrogen. Liu et al. [40] studied the role of microstructure on the influence of hydrogen embrittlement in different advanced high-strength steels. They performed a hydrogen pre-charging and continue the hydrogen charging along with a linearly increasing stress test. In summary, the authors found that cracks in duplex stainless steels initiated in martensite region and/or at the interface of martensite and ferrite; and they propagated into ferrite or transverse martensite.

Zanotto et al. [41] performed a study on the stress corrosion cracking behavior of two stainless steels, UNS S32304 and UNS S32404, in chloride/thiosulphate solution. Samples were subjected to a SSRT while submerged in the solution. Maximum strains were compared in order to study the SCC behavior, along with optical inspection and $\mathrm{E}_{\text {ocp }}$ measurement. In general, both duplex stainless steels showed a reduction in strain when they were subjected to $\mathrm{NaCl}$ in presence of thiosulphate at different concentrations. However, when subjected to NACE TM-0177 solution, only UNS S32304 showed corrosion while UNS S32404 was immune, even at high concentrations of $\mathrm{S}_{2} \mathrm{O}_{3}^{2-}$. Authors claimed that the presence of significant amount of Mo in UNS S32404, play an important role in the resistance of SCC at these environmental.

Here, we expand on upon previous work with a focus on the influence of crevice corrosion phenomena and EAC mechanisms on the long term durability of high-strength corrosion-resistant prestressing reinforcements produced from duplex grades UNS S32205 and S32304. The results provide insights into the impact of stranding on CTLs and the potential susceptibility to brittle failure by EAC mechanisms (i.e., SCC and HE) during the service life of a prestressed concrete structure. Testing for crevice corrosion resistance was performed using simulated 7-wire strands in alka-

Table 1

Chemical composition and ultimate tensile strength (UTS) of alloys investigated.

\begin{tabular}{|c|c|c|c|c|c|c|c|c|c|c|c|c|c|}
\hline \multirow[t]{2}{*}{ Alloy (UNS No.) } & \multicolumn{12}{|c|}{ Composition (\%) - Fe balance } & \multirow[t]{2}{*}{ UTS (MPa) } \\
\hline & $\mathrm{C}$ & Mn & $P$ & $S$ & $\mathrm{Si}$ & $\mathrm{Ni}$ & $\mathrm{Cr}$ & Mo & $\mathrm{Cu}$ & V & $\mathrm{N}$ & $\mathrm{Al}$ & \\
\hline S32205 & 0.004 & 0.82 & 0.023 & $<0.001$ & 0.51 & 5.1 & 22.1 & 3.2 & 0.21 & 0.12 & 0.22 & - & 1349 \\
\hline S32304 & 0.018 & 0.87 & 0.011 & 0.001 & 0.43 & 4.8 & 22.3 & 0.31 & 0.23 & 0.07 & 0.14 & - & 1247 \\
\hline
\end{tabular}


line and carbonated solutions with the addition of $\mathrm{Cl}^{-}$. SCC susceptibility was evaluated using slow strain rate testing (SSRT) techniques in alkaline and carbonated solutions containing $\mathrm{Cl}^{-}$. $\mathrm{HE}$ susceptibility was evaluated using excessive cathodic polarization to generate $\mathrm{H}^{+}$. The following sections provide a summary of the materials studied, the methods used, the results of the study, and the ramifications of those results.

\section{Materials and methods}

\subsection{Materials}

Stainless steel alloys selected for the investigation included duplex grades S32205 and S32304. Stainless steel alloys were strengthened by cold drawing with the assistance of a spring wire manufacturer. A target final wire diameter similar to that typically used for prestressing reinforcement $(3-5 \mathrm{~mm})$ was specified for the cold drawing operation along with a target tensile strength of approximately $1300 \mathrm{MPa}$. Measured chemical compositions and ultimate tensile strengths (UTS) of the as-received materials are provided in Table 1. The chemical composition of all materials used were within the limits specified in ASTM A276 [42].

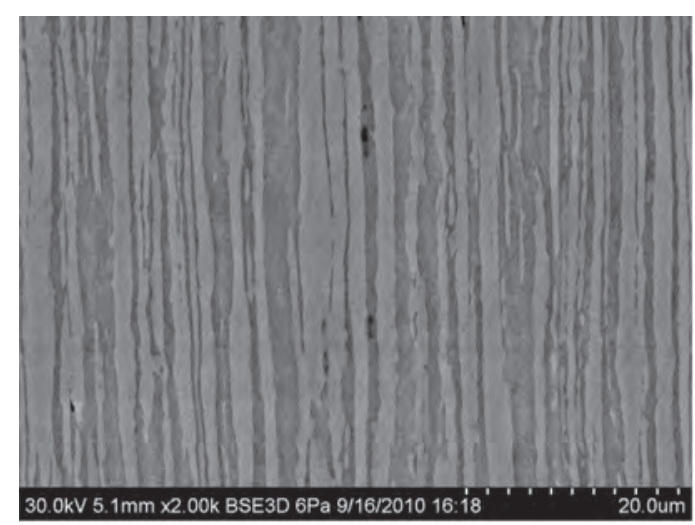

(a) S32205 longitudinal

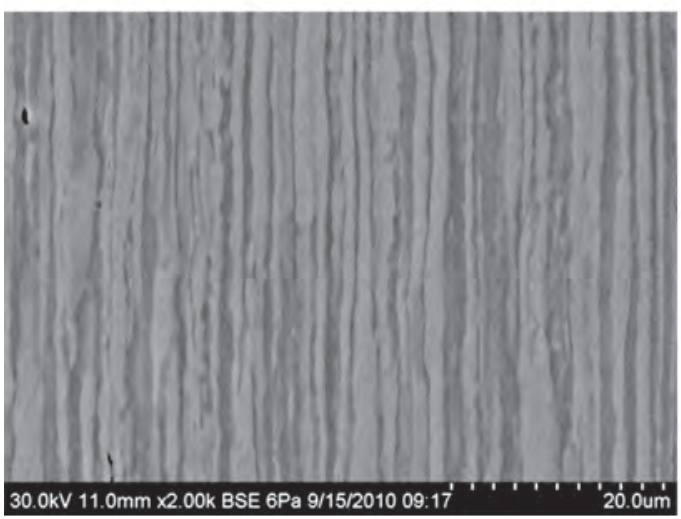

(c) S32304 longitudinal
Scanning electron micrographs of etched microstructures are shown in Fig. 1 in both longitudinal and transverse orientations with respect to the drawing direction. Duplex grades were electroetched in a $20 \% \mathrm{NaOH}$ solution with an applied potential

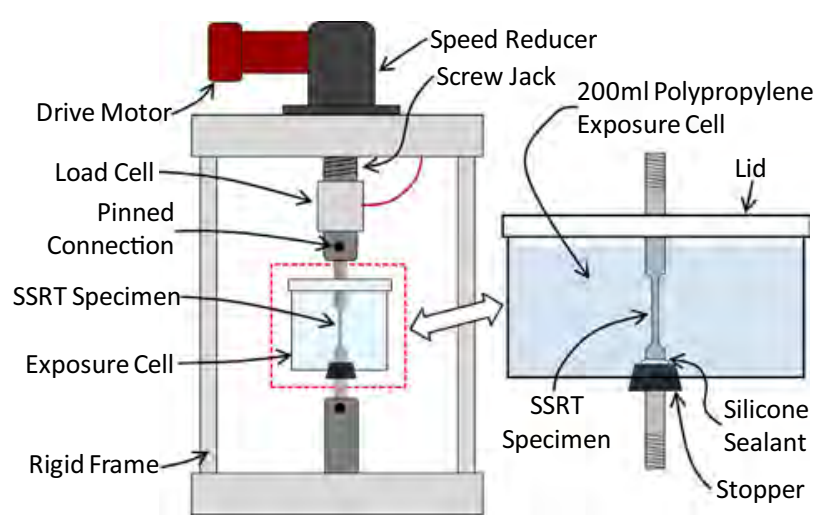

Fig. 3. Apparatus and exposure cell used for SSRTs.

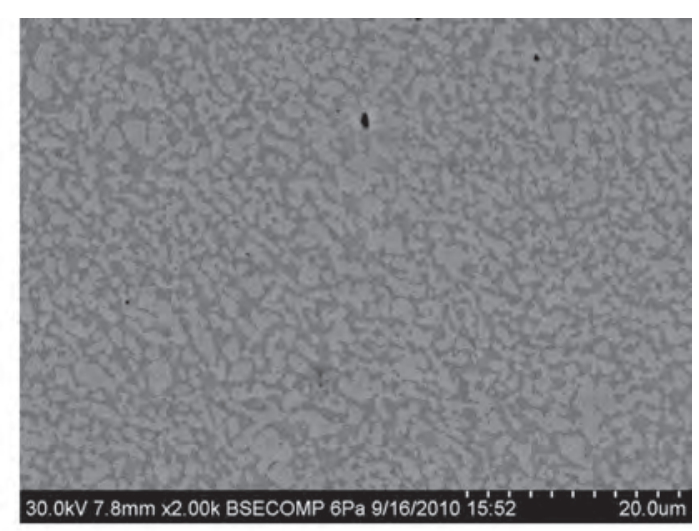

(b) S32205 transverse

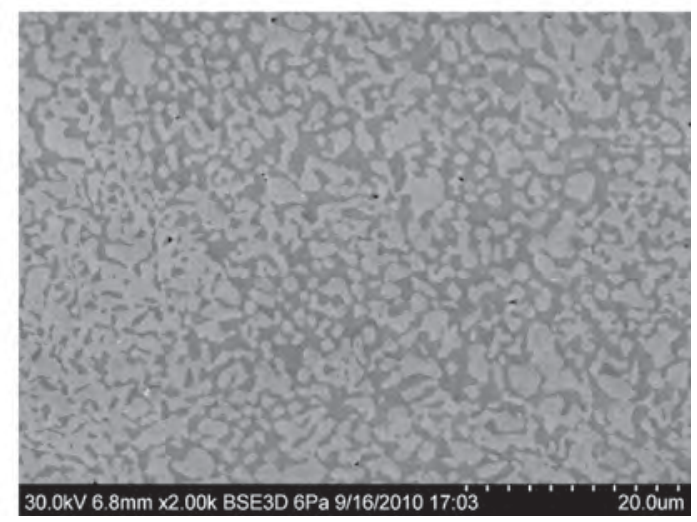

(d) S32304 transverse

Fig. 1. Longitudinal and transverse microstructure of as received UNS S32205 and S32304 materials following cold drawing.

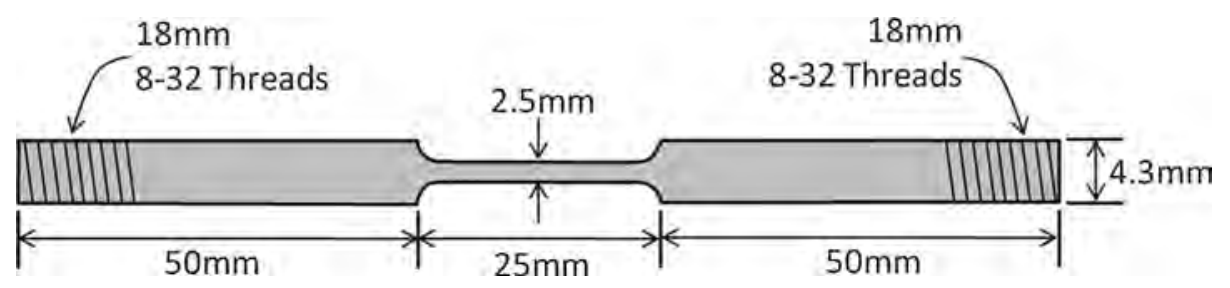

Fig. 2. Cylindrical dogbone specimen used for all SSRTs. 
of $4 \mathrm{~V}$, with austenite etching bright and ferrite etching dark. Significant longitudinal grain alignment and elongation that was axisymmetric with the drawing direction were observed as a result of the heavy cold drawing. An approximately 50/50 proportion of austenite and ferrite (measured using quantitative image analysis) was observed in both UNS S32205 and S32304.

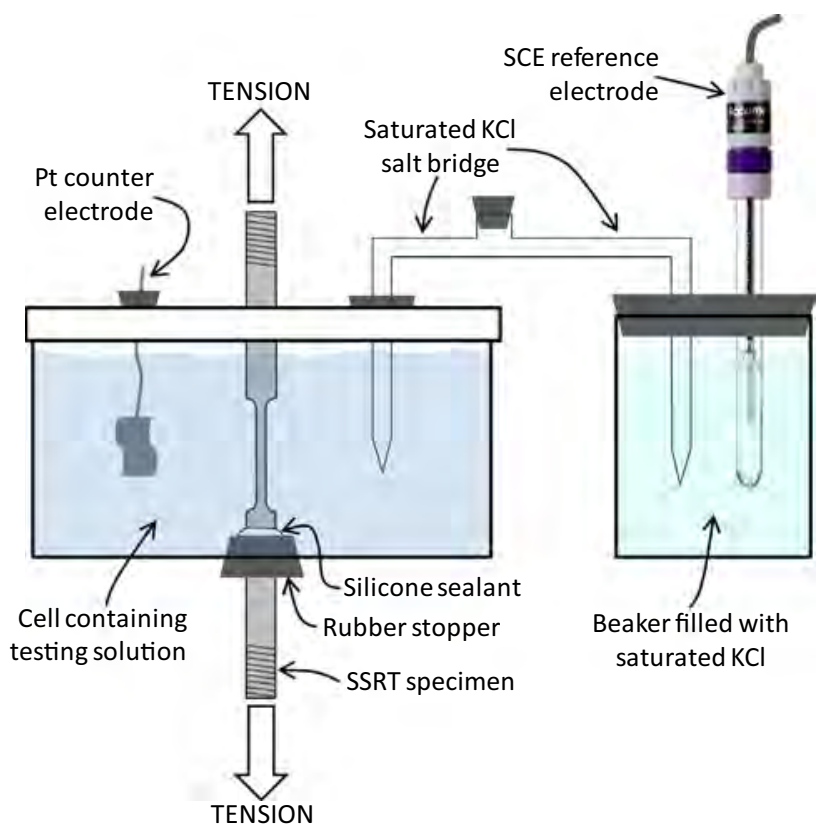

Fig. 4. Experimental setup for HE SSRTs.

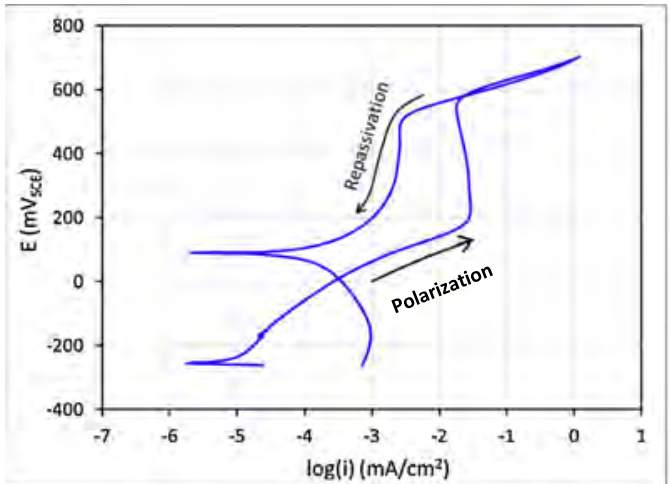

(a) Wire specimen at $0.5 \mathrm{M} \mathrm{Cl}^{-}$

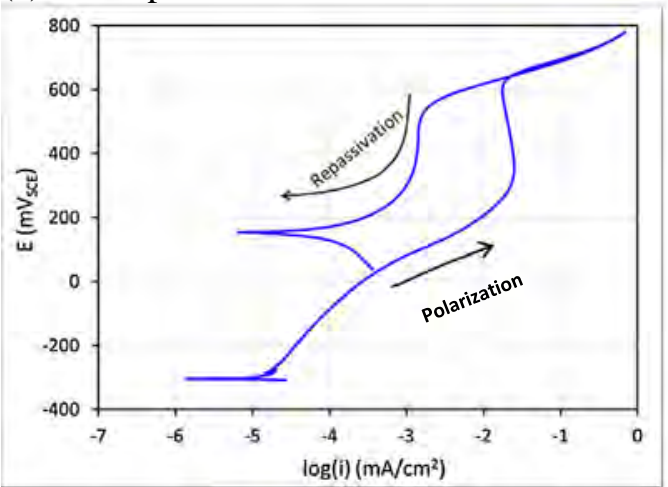

(c) Strand specimen at $0.5 \mathrm{M} \mathrm{Cl}^{-}$

\subsection{Exposure solutions}

Experiments were conducted at a temperature of $24^{\circ} \mathrm{C}\left(75^{\circ} \mathrm{F}\right)$. Two simulated concrete pore solutions were used to represent alkaline and carbonated concrete. Alkaline solutions consisted of $4 \mathrm{~g} / \mathrm{L}$ of $\mathrm{Ca}(\mathrm{OH})_{2}$ with a pH of 12.5 . This solution was used to represent aging concrete which has lost much of its highly soluble cations (e.g., $\mathrm{K}^{+}, \mathrm{Na}^{+}$) due to leaching [31]. Carbonated solutions used to simulate concrete that has fully carbonated or acidified through the cover depth contained $0.3 \mathrm{M} \mathrm{NaHCO}_{3}$ and $0.1 \mathrm{M} \mathrm{Na}_{2} \mathrm{CO}_{3}$ with a pH of 9.5 [31]. To simulate a marine exposure, $\mathrm{Cl}^{-}$was added as $\mathrm{NaCl}$ at concentrations of up to $1.00 \mathrm{M}$. For testing of crevice corrosion phenomena, $\mathrm{Cl}^{-}$concentrations were selected based on the results of single wires with the goal of testing only exposures that bracketed the CTL of each alloy. For SCC testing, $\mathrm{Cl}^{-}$was added at a concentration of $0.5 \mathrm{M}$ to simulate an exposure to seawater.

\subsection{Investigation of crevice corrosion mechanisms}

\subsubsection{Specimen preparation}

In order to compare the performances of single wires and 7-wire strands, simulated prestressing strands of grades UNS S32205 and S32304 were produced. To form a strand, seven wires were bundled together and secured using plastic cable ties. A wire for electrical contact was then soldered onto the end of the bundle. Following the soldering operation, the ends of the strands were encapsulated in epoxy. Details on the preparation techniques used to prepare wire and strand test specimens are provided in [15]. The exposed surface area of each strand specimen was $24.5 \mathrm{~cm}^{2}$. A total of eight specimens of S32205 and eight specimens of S32304 were produced. Cyclic potentiodynamic polarization (CPP) techniques were used to evaluate the influence of stranding on the $\mathrm{Cl}^{-}$induced corrosion resistance of S32205 and S32304. Each specimen was conditioned for a period of five days prior to exposure to $\mathrm{Cl}^{-}$to form a stable passive film on its surface. The five day duration was based on the results of previous research on these alloys [31].

\subsubsection{Cyclic potentiodynamic polarization studies}

All CPP experiments were conducted using a typical three electrode electrochemical cell consisting of a Pt foil counter electrode with surface area of $4 \mathrm{~cm}^{2}$, a saturated calomel reference electrode (SCE), and the working electrode being the test specimen. A solution volume of $250 \mathrm{ml}$ was used for wire specimens to ensure a minimum solution-volume-to-specimen-surface-area ratio of $0.2 \mathrm{ml}$ / $\mathrm{mm}^{2}$. Due to the increased exposed surface area in stranded specimens, a larger

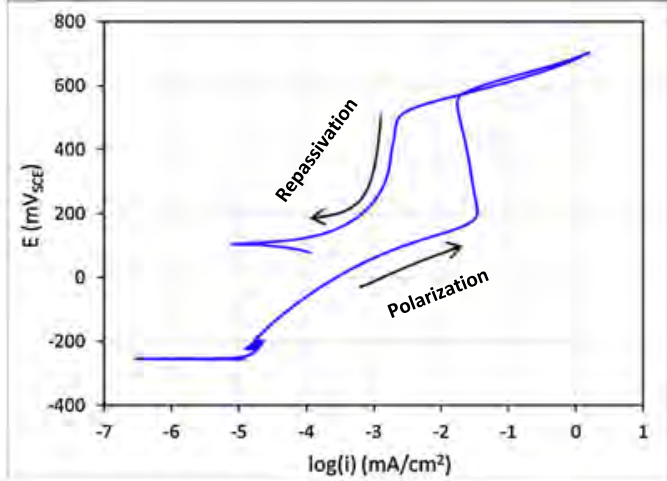

(b) Wire specimen at $1.0 \mathrm{M} \mathrm{Cl}^{-}$

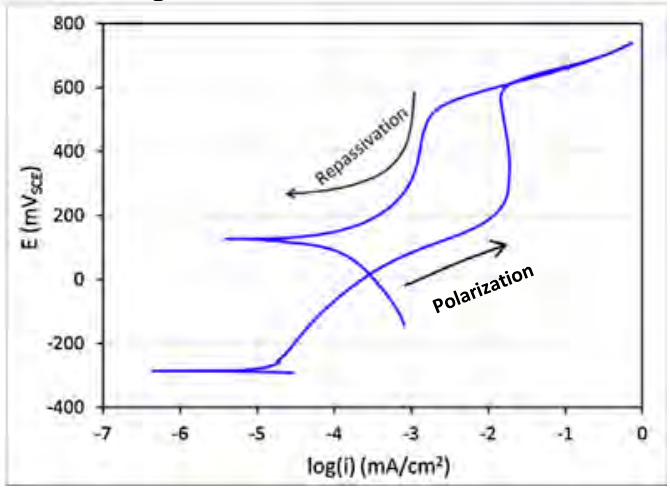

(d) Strand specimen at $1.0 \mathrm{M} \mathrm{Cl}^{-}$

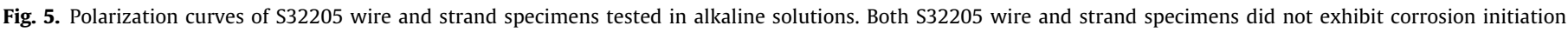
during CPP testing and repassivated at $\mathrm{Cl}^{-}$concentrations of up to $1.0 \mathrm{M}$. 
solution volume of $700 \mathrm{ml}$ was required. This solution-volume-to-specimen-sur face-area ratio is based on requirements of ASTM G31 [43].

The reference, counter, and working electrodes were connected to a potentiostat (Reference 600, GAMRY) to carry out the CPP scan. A scan rate of $1 \mathrm{mV} / \mathrm{s}$ was used for all experiments. This scan rate is higher than that typically employed for the study of corrosion behavior solutions that simulate the environment in concrete $(0.1-0.17 \mathrm{mV} / \mathrm{s})$. The increased scan rate has been shown to yield slightly higher values of breakdown and protective potentials [44]. All potentials are given on the SCE scale. Potentials were anodically scanned from $-25 \mathrm{mV}$ versus the steady $\mathrm{E}_{\text {corr }}$ until either $\mathrm{O}_{2}$ was evolved or corrosion initiation occurred. In either case, potential scans were reversed after a current increase of approximately two orders of magnitude beyond the passive condition, and the potential was decreased to the original $E_{\text {corr }}$ at the same $1 \mathrm{mV} / \mathrm{s}$ scan rate. Each experiment utilized a new sample that underwent its own conditioning procedure. Following testing, specimens were examined for unintended crevice corrosion by destructively examining the sample using an optical microscope. If unintended crevice corrosion had occurred (i.e., corrosion that was not isolated within the intended exposed surface area), the data were deemed aberrant, and the experiment was repeated with a new specimen.

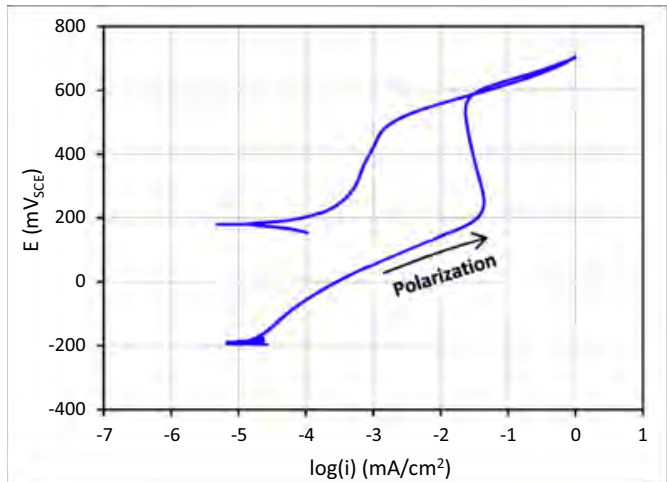

(a) Wire specimen at $0.25 \mathrm{M} \mathrm{Cl}^{-}$

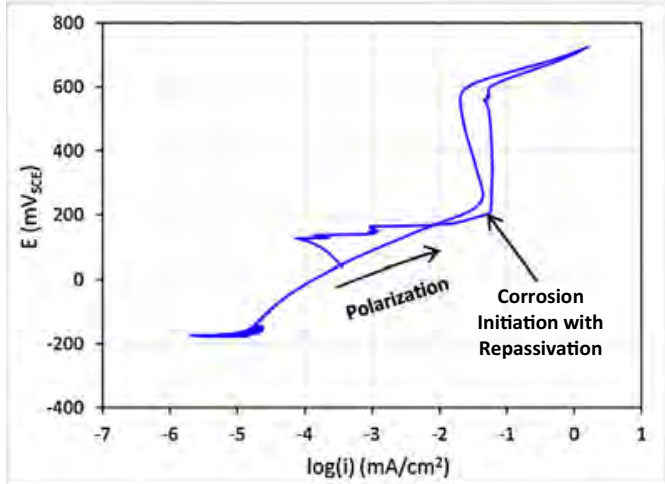

(c) Wire specimen at $1.0 \mathrm{M} \mathrm{Cl}$

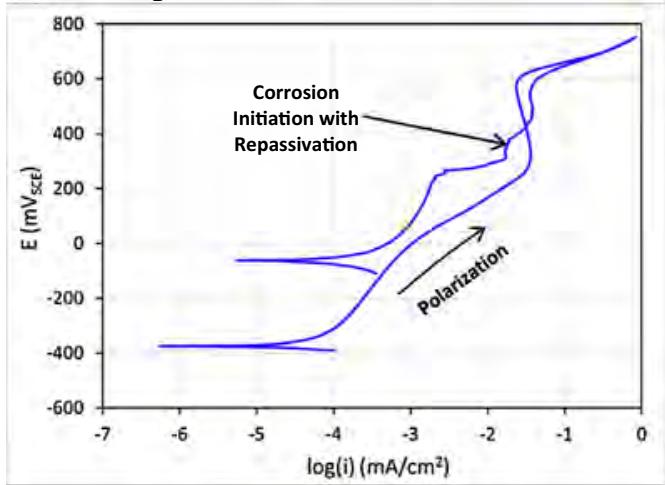

(e) Strand specimen at $0.5 \mathrm{M} \mathrm{Cl}^{-}$
The first CPP experiments were conducted on duplicate specimens in alkaline and carbonated solutions containing $0.5 \mathrm{M} \mathrm{Cl}^{-}$to provide an initial indication of corrosion resistance. Based on the results of tests in $0.5 \mathrm{M} \mathrm{Cl}^{-}$, the concentration of $\mathrm{Cl}^{-}$was either increased or decreased for the remaining tests. For example, if the first series of tests on an $\mathrm{S} 32205$ strand in $0.5 \mathrm{M} \mathrm{Cl}^{-}$containing pore solutions showed full repassivation during the CPP scan, the second series of tests would be performed at an increased $\mathrm{Cl}^{-}$concentration of $1 \mathrm{M}$.

\subsection{Environmentally-assisted cracking susceptibility by slow strain rate testing}

2.4.1. Manufacture of test specimens

Cylindrical dogbone specimens were machined from S32205 and S32304 wires for use in the SSRT setup. The schematic shown in Fig. 2 depicts the geometry of the cylindrical dogbone specimen used for all SSRTs. For each SSRT, the exposed region of the cylindrical dogbone specimen was polished with SiC paper up to 600 grit followed by $6 \mu \mathrm{m}$ diamond paste.

\subsubsection{Slow strain rate testing method}

Fig. 3 shows the apparatus used for all SSRTs and the exposure cell used for SCC and HE tests.

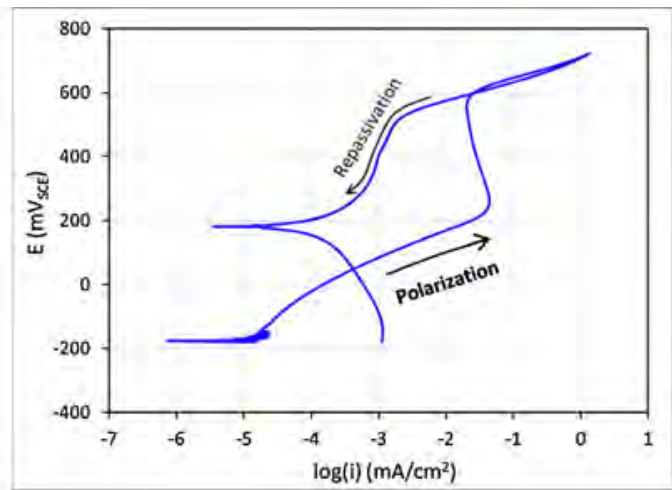

(b) Wire specimen at $0.5 \mathrm{M} \mathrm{Cl}^{-}$

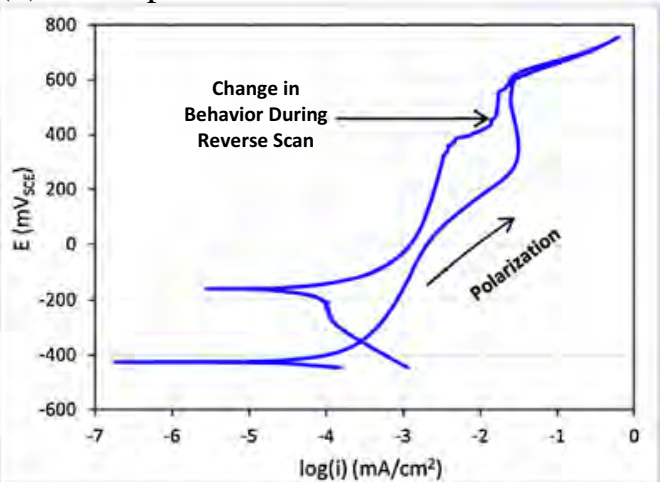

(d) Strand specimen at $0.25 \mathrm{M} \mathrm{Cl}^{-}$

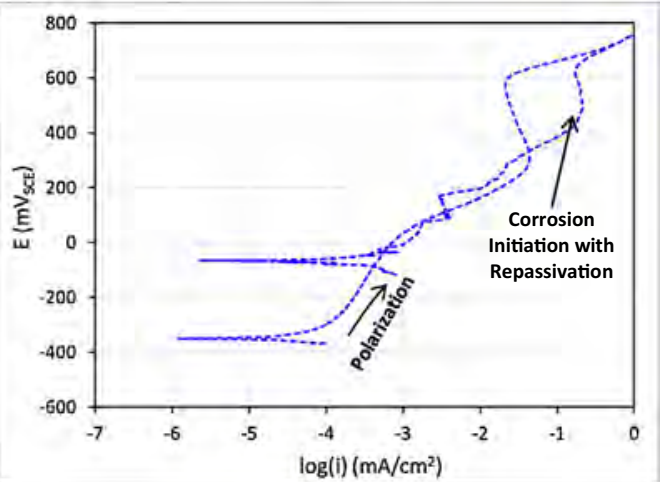

(f) Strand specimen at $1.0 \mathrm{M} \mathrm{Cl}^{-}$

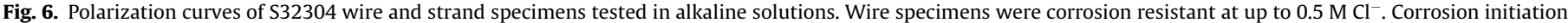

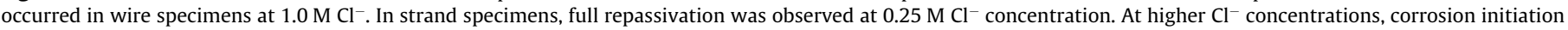
was observed in strand specimens. 
Specimens that were exposed to solutions were placed in a $200 \mathrm{ml}(6.8-\mathrm{oz})$ polypropylene exposure cell. Once the specimen and exposure cell were secured in the SSRT apparatus, the testing solution was added to the cell, required instrumentation was connected, and the SSRT was commenced. A constant displacement rate was applied using an RPM calibration of the variable speed drive motor. A constant displacement rate of $25 \cdot 10^{-6} \mathrm{~mm} / \mathrm{s}\left(1 \cdot 10^{-6} \mathrm{in}\right.$./s) was used for all SSRTs. This displacement rate corresponds to a strain rate of $10^{-6} \mathrm{~s}^{-1}$ for the $25 \mathrm{~mm}$ (1 in.) gage length with reduced cross section. The $10^{-6} \mathrm{~s}^{-1}$ strain rate was selected, as it has been shown to result in the most significant damage by SCC and HE and, thus, provides a conservative assessment of EAC susceptibility [45]. The duration of each SSRT was approximately $50 \mathrm{hr}$. During the SSRT, load in the specimen was monitored using a calibrated tension load cell connected between the screw jack shaft and the coupler used to secure the dogbone specimen. Following the SSRT, fractured specimens were examined using optical and scanning electron microscopy (SEM). Damage was quantified by interpretation of the stress vs. strain behavior and measurements of the reduction in area of the fracture surface using optical microscopy.

\subsubsection{Stress corrosion cracking susceptibility}

The SSRT method was used to evaluate the SCC susceptibility of S32205 and S32304 in alkaline and carbonated solutions with the addition of $0.5 \mathrm{M} \mathrm{Cl}^{-}$. All SSRTs were conducted at open circuit, i.e., no external potential was applied to the specimens. The test setup used a simple exposure cell like that shown in Fig. 3 with no electrodes immersed in solution for electrochemical measurements.

\subsubsection{Hydrogen embrittlement susceptibility}

The SSRT method was used to evaluate the HE susceptibility of S32205 and S32304 in alkaline and carbonated solutions, with an applied cathodic polarization to generate hydrogen. While the exposure cell design was similar to that in Fig. 3, additional electrodes and a potentiostat were necessary to apply the cathodic overpotential to the specimen. Fig. 4 shows the experimental setup used for HE SSRTs.

A Pt foil counter electrode with a surface area of $4 \mathrm{~cm}^{2}$ was placed through an access hole in the lid of the exposure cell. An SCE reference electrode was placed in an adjacent beaker filled with saturated $\mathrm{KCl}$ and sealed with a rubber stopper. The reference electrode was electrolytically connected to the exposure cell with a salt bridge filled with saturated $\mathrm{KCl}$. The dogbone specimen acted as the working electrode. The counter, reference, and working electrodes were connected to a GAMRY Reference 600 potentiostat that was used to apply the potentiostatic cathodic polarization.
HE tests were performed at potentials of $-1.00 \mathrm{~V}$ and $-0.82 \mathrm{~V}$ in alkaline and carbonated solutions, respectively. The potentiostatic polarization was applied to the specimen in conjunction with commencing the SSRT. These potentials lie $20 \mathrm{mV}$ below the $\mathrm{E}_{\mathrm{H}+\mathrm{H} 2}$ "Hydrogen" line at the $\mathrm{pH}$ of 12.5 in alkaline solutions and 9.5 in carbonated solutions (on the SCE scale: $\mathrm{E}_{\text {applied }}=-0.242-0.059 \cdot \mathrm{pH}$ in volts). With the potential shifted to below $\mathrm{E}_{\mathrm{H}+/ \mathrm{H} 2}$, atomic $\mathrm{H}$ is generated on the surface of the working electrode, which simulates a cathodic overprotection of the steel that is known to cause HE damage. This atomic $\mathrm{H}$ may be absorbed into the metal, resulting in embrittlement, or it may combine to form $\mathrm{H}_{2}$ as a gas [30].

\section{Results and discussion}

\subsection{Influence of stranding on crevice corrosion}

Figs. 5 and 6 show results of CPP testing of S32205 and S32304 wire and strand specimens, respectively, tested in alkaline solutions. CPP experiments were conducted at $\mathrm{Cl}^{-}$concentrations of 0.5 and $1 \mathrm{M}$ for S32205 and $0.25,0.5$, and $1 \mathrm{M}$ for S32304. Following the specimen conditioning period, measured values of $\mathrm{E}_{\text {corr }}$ in S32205 and S32304 strands were shifted negatively by approximately $200 \mathrm{mV}$ when compared with wires. This shift was also observed in tests of ASTM A416 carbon steel prestressing strands (see [15]) and has been hypothesized to be due to aeration/concentration cell effects in the stranded geometry that result in a measured cathodic polarization of $\mathrm{E}_{\text {corr }}$.

In both alloys, at a potential of approximately $200 \mathrm{mV}$, a shift in polarization behavior is observed. This change is likely related to the oxidation of $\mathrm{Cr}_{2} \mathrm{O}_{3}$ in the passive film to form $\mathrm{CrO}_{4}^{2-}$ (by $\mathrm{Cr}_{2}-$ $\mathrm{O}_{3}+5 \mathrm{H}_{2} \mathrm{O} \rightarrow 2 \mathrm{CrO}_{4}^{2-}+10 \mathrm{H}^{+}+6 \mathrm{e}^{-}$), which will become thermodynamically viable at potentials above $225 \mathrm{mV}$ when $\mathrm{pH}$ is approximately 12.5 [46]. Following the breakdown of the $\mathrm{Cr}_{2} \mathrm{O}_{3}$ film, current densities actually decrease, which indicates the passivating role of $\mathrm{Ni}$ and $\mathrm{Fe}$ at elevated electrochemical potentials [47].

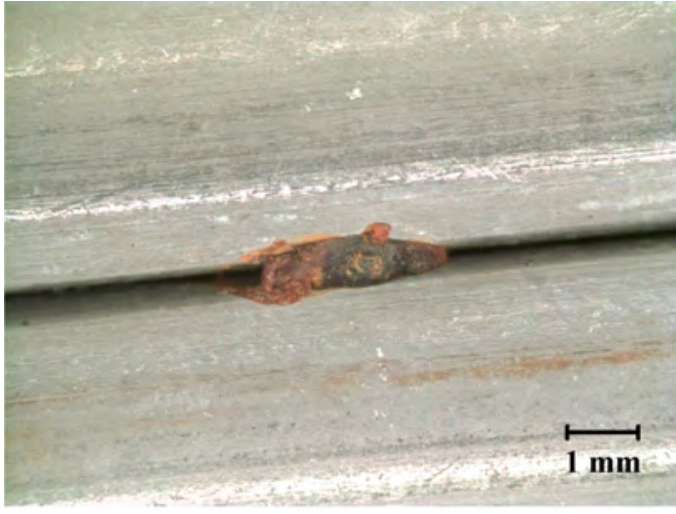

(a) Crevice corrosion

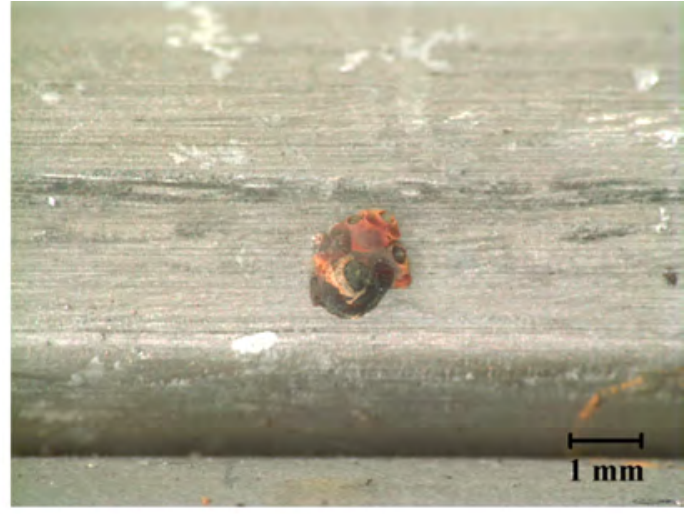

(b) Pitting corrosion

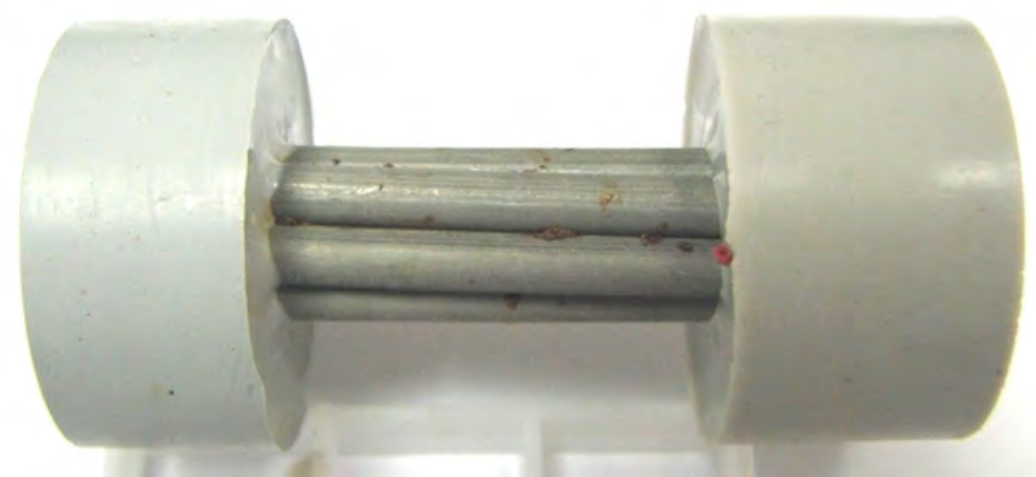

(c) S32304 strand specimen

Fig. 7. Corrosion damage in $\mathrm{S} 32304$ strand specimen following testing in alkaline solution with $0.5 \mathrm{M} \mathrm{Cl}^{-}$. 
Current density rises again at a potential of approximately $650 \mathrm{mV}$ at the pH of 12.5 as $\mathrm{H}_{2} \mathrm{O}$ is oxidized and $\mathrm{O}_{2}$ is evolved $\left(2 \mathrm{H}_{2} \mathrm{O} \rightarrow\right.$ $\mathrm{O}_{2}+4 \mathrm{H}^{+}+4 \mathrm{e}^{-}$) [47].

In alkaline solutions, no degradation in corrosion resistance was observed in the S32205 wire and strand specimens that did not exhibit corrosion initiation at $\mathrm{Cl}^{-}$concentrations up to $1 \mathrm{M}$. Stranding did reduce the corrosion resistance of the S32304 stranded specimens when compared with the wire specimens, which at a $\mathrm{Cl}^{-}$concentration of $0.5 \mathrm{M}$ was not susceptible to corrosion initiation in the single wire geometry but was susceptible when tested in the seven-wire strand geometry. Corrosion initiation in both the S32304 wire and strand specimens occurred within the $\mathrm{O}_{2}$ evolution region with electrochemical behavior that deviated from full repassivation behavior at all potentials and led to repassivation potentials of approximately -100 to $-200 \mathrm{mV}$ where the reverse polarization curve intersected the forward polarization curve.

Fig. 7 depicts corrosion damage in an S32304 specimen tested in an alkaline solution with $0.5 \mathrm{M} \mathrm{Cl}^{-}$. Corrosion damage in the S32304 strand was largely partitioned to the crevice regions where impingement between the individual wires in the strand occurred (see Fig. 7(a)). Moderate pitting corrosion was also observed on the outer wires (see Fig. 7(b)).

Figs. 8 and 9 show results of CPP testing of S32205 and S32304 wire and strand specimens, respectively, tested in carbonated solutions at the same $\mathrm{Cl}^{-}$concentrations studied in alkaline solutions (i.e., $0.5 \mathrm{M}$ and $1.0 \mathrm{M}$ for $\mathrm{S} 32205$ and $0.25 \mathrm{M}, 0.5 \mathrm{M}$, and $1.0 \mathrm{M}$ for S32304). The initial $E_{\text {corr }}$ of the S32205 and the S32304 strands in carbonated solutions was shifted negatively by approximately $100 \mathrm{mV}$ relative to single wires of the same alloy. Similar to the behavior observed in alkaline solutions, a change in polarization behavior was observed as the $\mathrm{Cr}_{2} \mathrm{O}_{3}$ was oxidized and $\mathrm{O}_{2}$ was evolved which is likely due to geometric effects and the availability of reactants in interstices of the strand. However, potentials at which these two reactions occurred increased by approximately $200 \mathrm{mV}$ due to the reduced $\mathrm{pH}$ present in carbonated solutions (i.e., $(12.5-9) 0.059=0.206 \mathrm{~V}=206 \mathrm{mV}$ ). Here again, the $\mathrm{S} 32205$ wire and strand specimens were fully resistant to corrosion initiation at $\mathrm{Cl}^{-}$concentrations up to $1 \mathrm{M}$. The corrosion resistance of the S32304 strand was also found to be reduced in carbonated solutions when compared with the wire specimens, with minor crevice corrosion at $\mathrm{Cl}^{-}$concentrations of $0.25 \mathrm{M}$.

Once localized corrosion initiated in S32304 strands, current densities associated with corrosion propagation were much lower than those observed in single wires (approximately $0.1 \mathrm{~mA} / \mathrm{cm}^{2}$ in strands vs. $10 \mathrm{~mA} / \mathrm{cm}^{2}$ in wires). These low current densities likely corresponded to a highly localized form of corrosion (crevice/pitting) in which current contributions were negated when normalized against the relatively large exposed surface area of the strand sample.

The results of all CPP experiments on S32205 and S32304 wire and strand specimens are summarized in Fig. 10 according to the observed corrosion behavior. Metastable pitting/crevice corrosion corresponded to minor breakdown in passivity evidenced by variations in current during polarization sweeps that included repassivation well above $E_{\text {corr }}$ with current densities in the reverse cycle of the CPP curve that are generally less than the initial polarization. Stable pitting/crevice corrosion corresponded to stable increased current densities due to a breakdown in passivity that remained high during reverse cycle of the CPP curve and high currents continued to near $\mathrm{E}_{\text {corr }}$. As discussed above, the corrosion resistance of S32304 is jeopardized in the stranded geometry. One explanation for the superior performance of S32205 is its chemical composition. As shown in Table 1, S32205 contains amounts of $\mathrm{Ni}$ and $\mathrm{Cr}$ similar to those of S32304 but increased amounts of Mo (10X

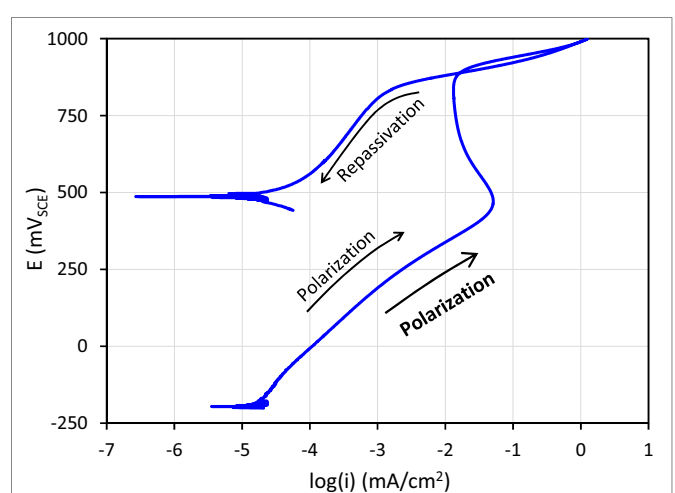

(a) Wire specimen at $0.5 \mathrm{M} \mathrm{Cl}^{-}$

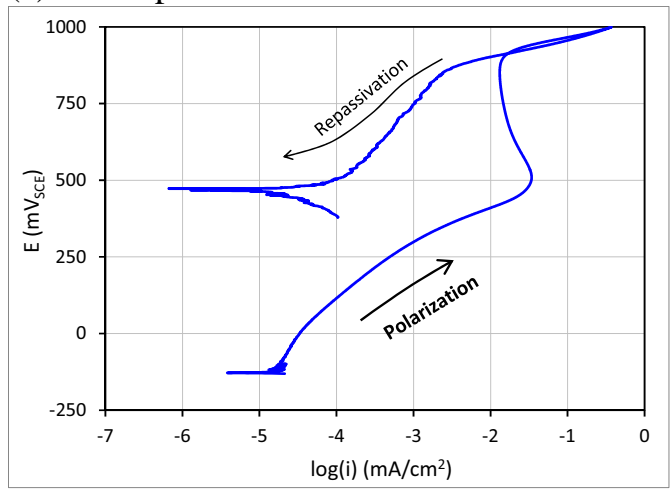

(c) Strand specimen at $0.5 \mathrm{M} \mathrm{Cl}^{-}$

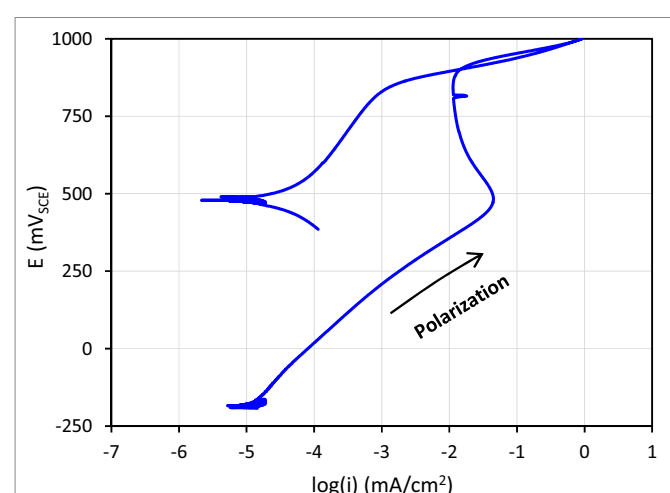

(b) W ire specimen at $1.0 \mathrm{M} \mathrm{Cl}^{-}$

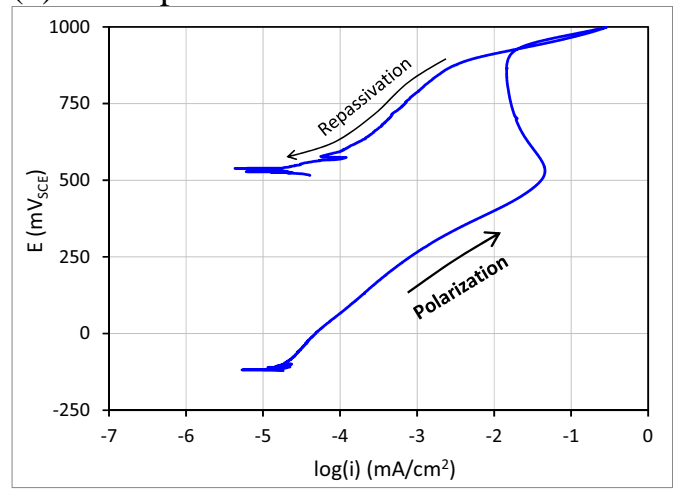

(d) Strand specimen at $1.0 \mathrm{M} \mathrm{Cl}^{-}$

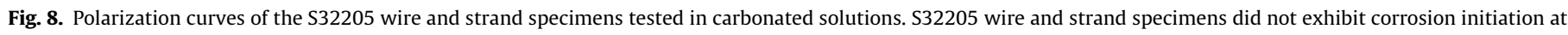
$\mathrm{Cl}^{-}$concentrations of up to $1.0 \mathrm{M}$ in carbonated solutions. 
higher in S32205) and N (1.6X higher in S32205). Previous studies of the pitting corrosion resistance of duplex stainless steels S32205 and S32304 found that Mo and N are particularly effective in increasing corrosion resistance in $\mathrm{Cl}^{-}$containing neutral and acidic solutions [48]. The effectiveness of Mo and $\mathrm{N}$ is also reflected in the pitting resistance equivalency number (PREN) value, with Mo and $\mathrm{N}$ making contributions of 3.3 and 30 times that of $\mathrm{Cr}$, respectively [49]. Because conditions within the crevice during corrosion propagation are similar to an acidic $\mathrm{Cl}^{-}$solution, it is hypothesized that the superior corrosion resistance of S32205 results from its increased Mo and $\mathrm{N}$ content. Accordingly, this increased corrosion resistance also typically comes with increased cost.

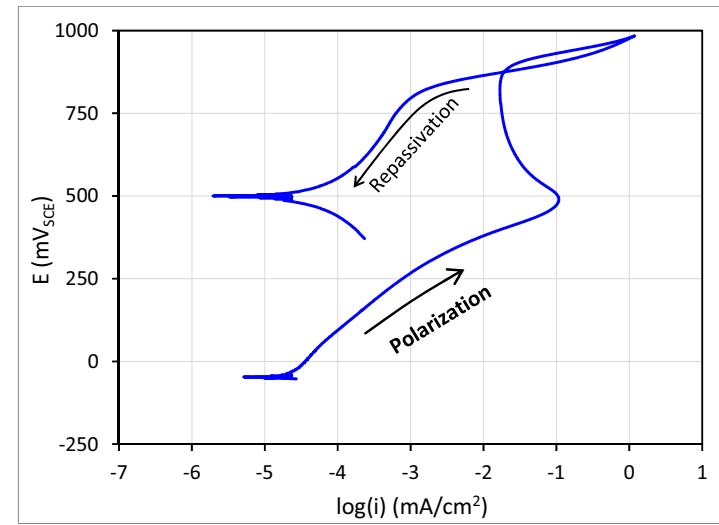

(a) Wire specimen at $0.25 \mathrm{M} \mathrm{Cl}^{-}$

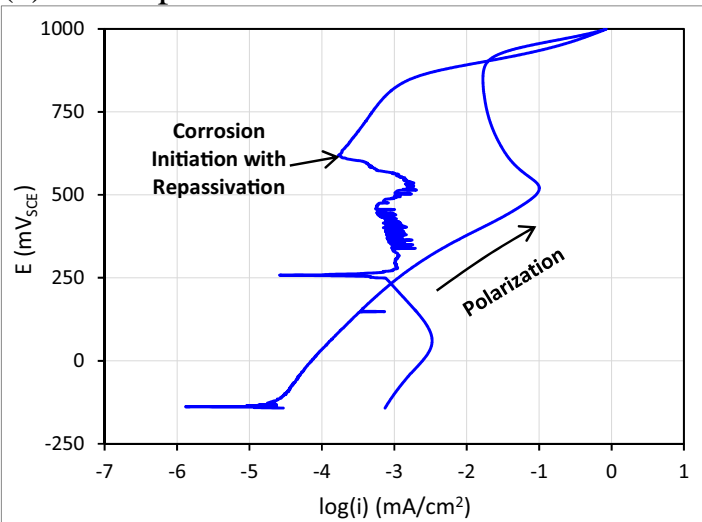

(c) Wire specimen at $1.0 \mathrm{M} \mathrm{Cl}^{-}$

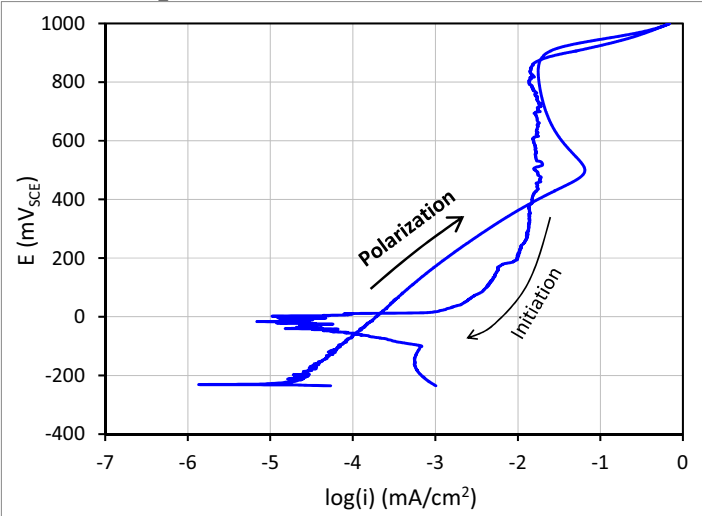

(e) Strand specimen at $0.5 \mathrm{M} \mathrm{Cl}^{-}$

\subsection{Environmentally-assisted cracking susceptibility}

The results of all SSRTs performed on S32205 and S32304 are plotted in Figs. 11 and 12, respectively. In order to eliminate abnormalities associated with SSRT load frame compliance, the elastic portion of the curve was truncated at a given stress level, and the data were shifted. Based on microscopical observations and the load vs. displacement curves, both S32205 and S32304 exhibited non-ductile failures in SSRTs with immediate necking after yield and no post-yield strain hardening. Little evidence of SCC and HE damage was present in any of the SSRT stress vs. time results, all of which had similar times to failure. The only indication

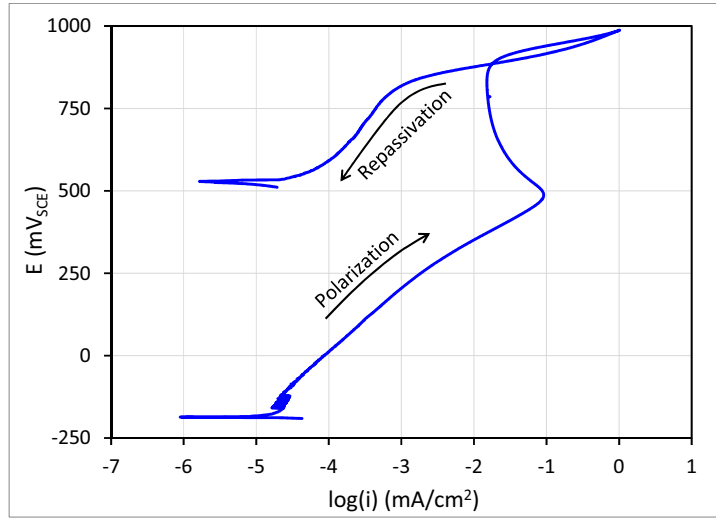

(b) Wire specimen at $0.5 \mathrm{M} \mathrm{Cl}^{-}$

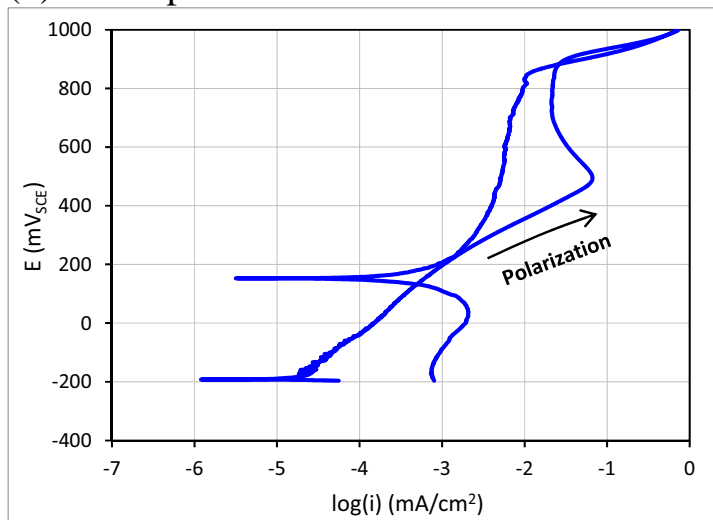

(d) Strand specimen at $0.25 \mathrm{M} \mathrm{Cl}^{-}$

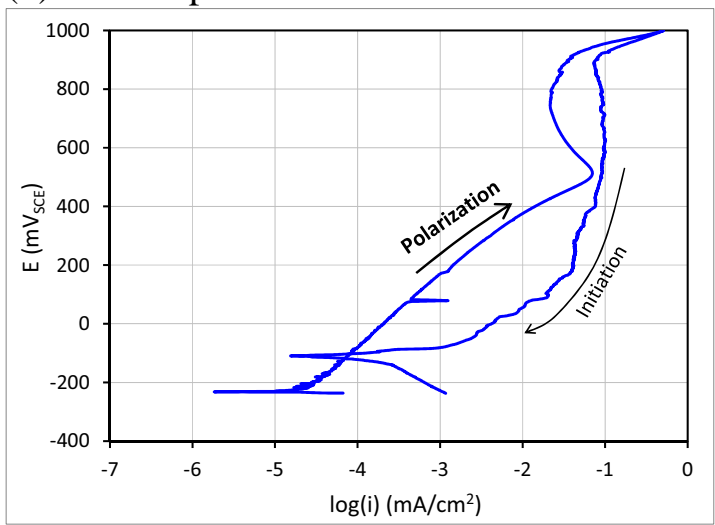

(f) Strand specimen at $1.0 \mathrm{M} \mathrm{Cl}^{-}$

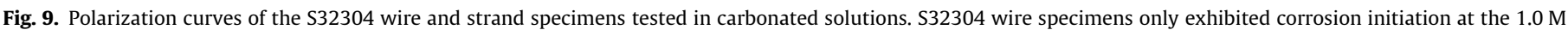

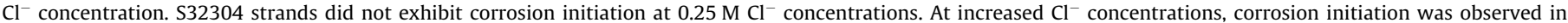
S32304 stand specimens. 


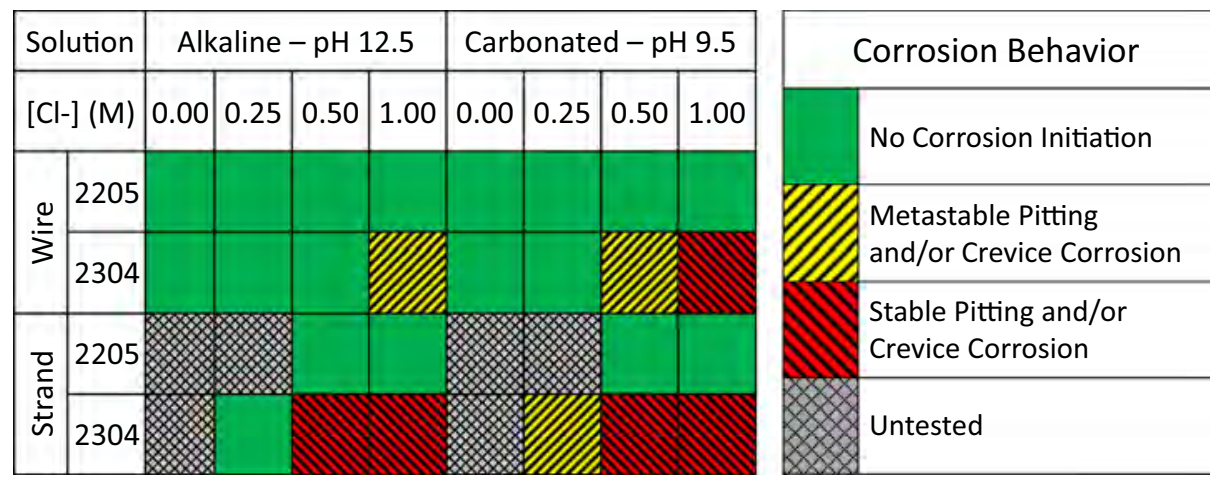

Fig. 10. Summary of CPP experimental results for S32205 and S32304 strands.

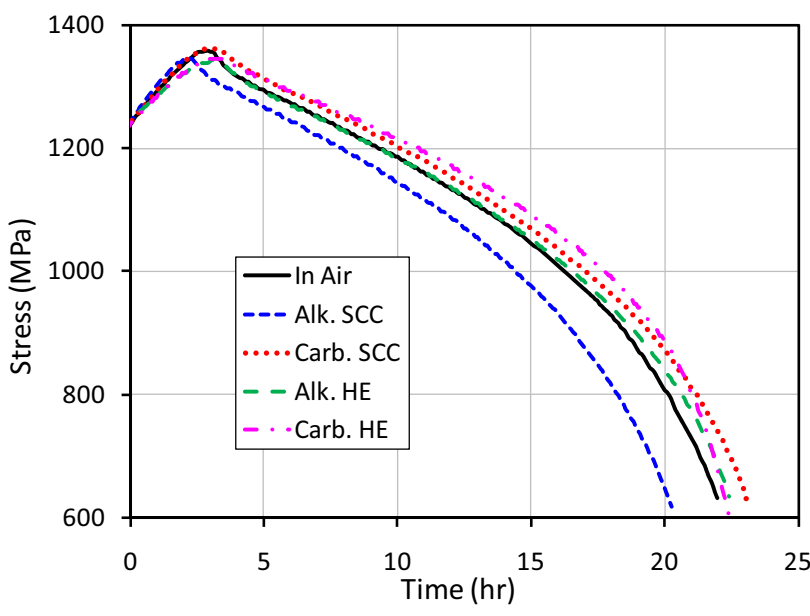

Fig. 11. SSRT results for S32205.

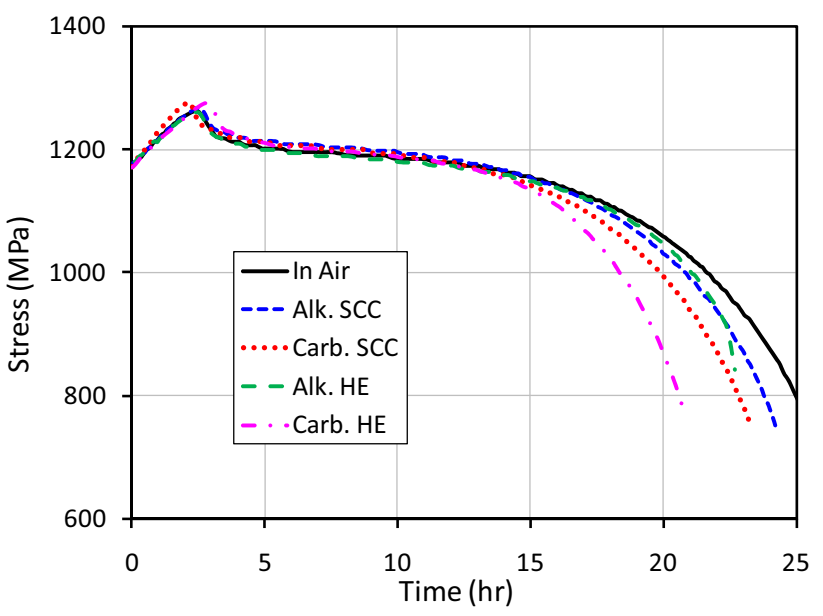

Fig. 12. SSRT results for S32304.

of damage was the increased strain softening in HE SSRTs just prior to failure. This strain softening in HE damaged samples is caused by cracks in the samples which reduce its axial stiffness and focus strain localization and plastic deformation into a reduced cross sectional area of non-embrittled material. Measurements of area reduction at fracture were far better indicators of damage by SCC and HE. The results of area reduction measurements from all SSRTs performed are shown in Fig. 13.

SCC SSRTs of S32205 and S32304 showed similar area reductions in air (approximately 80\% in S32205 and 73\% in S32304),

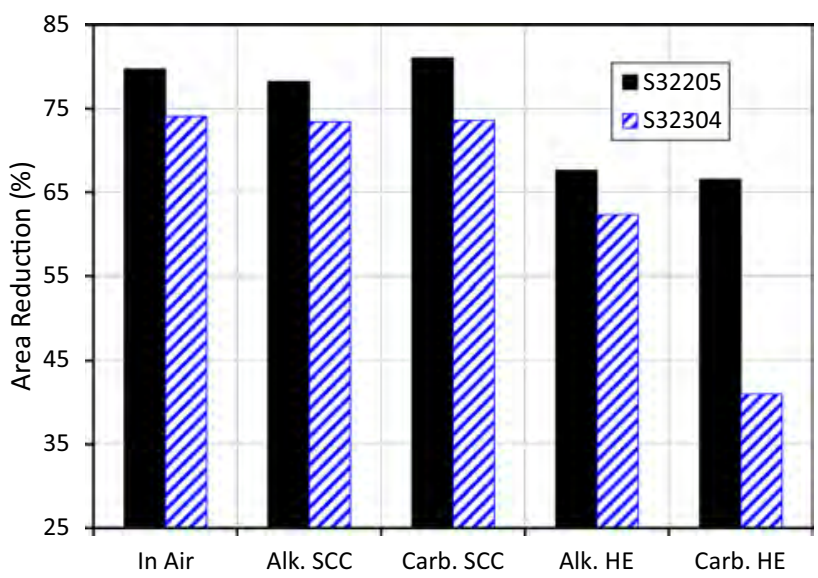

Fig. 13. Area reductions of S32205 and S32304 SSRT specimens at failure.

indicating no damage by SCC in alkaline and carbonated solutions. Damage by HE was evident in measured area reductions of S32205 and S32304 high-strength duplex stainless steels in alkaline and carbonated solutions. With the generation of $\mathrm{H}_{2}$ by cathodic polarization, area reductions decreased to approximately 67\% in S32205 and to less than 63\% in S32304. The most significant HE damage was in S32304 tested in carbonated solutions, which resulted in an area reduction of $41 \%$, almost half of the reduction when tested in air.

The trends in area reduction were confirmed when tested specimens were forensically examined with SEM. Fig. 14 depicts the typical failure observed in SCC SSRTs (S32205 shown). In all cases, no damage (i.e., cracking) resulting from SCC was evident in S32205 and S32304. However, significant cracking, delamination, and blistering were evident in all HE SSRTs (see typical damage in Fig. 15).

Cracks in HE specimens were present only in the necked region and increased in size nearer to the fracture surface, suggesting that significant plasticity was required to cause crack initiation and propagation. The most interesting observations of HE damage were made on the fracture surface itself. The SEM micrograph in Fig. 16 shows the fracture surface of the specimen in Fig. 15. Here, two distinct fracture morphologies are present. The center of the specimen displayed a ductile cup and cone failure with a shear lip around the perimeter and coalesced voids at the center. Around the perimeter of the specimen, a layer at the surface had fully delaminated from the ductile region at the center. Brittle cleavage fracture of this delaminated surface layer was discovered at higher magnifications. This is clearly shown in the SEM micrograph in Fig. 17 that corresponds to region "A" in Fig. 16. 


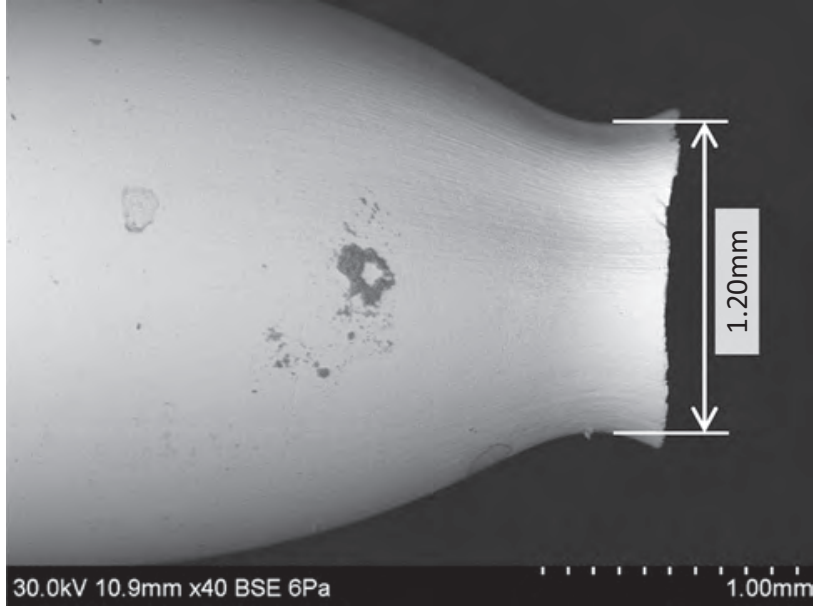

Fig. 14. No damage to S32205 SCC SSRT specimen in carbonated solution.

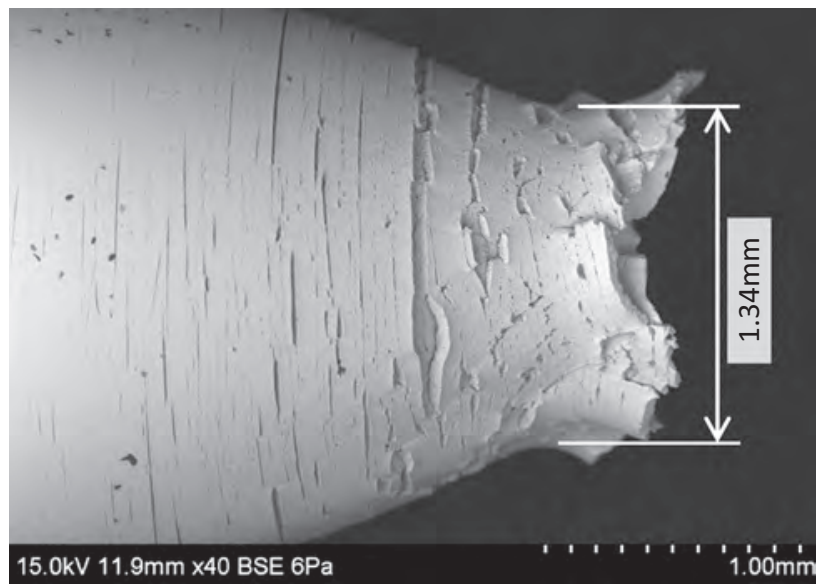

Fig. 15. Cracking in S32205 HE SSRT specimen in carbonated solution that was potentiostatically polarized to $-0.82 \mathrm{~V}$ vs. SCE.

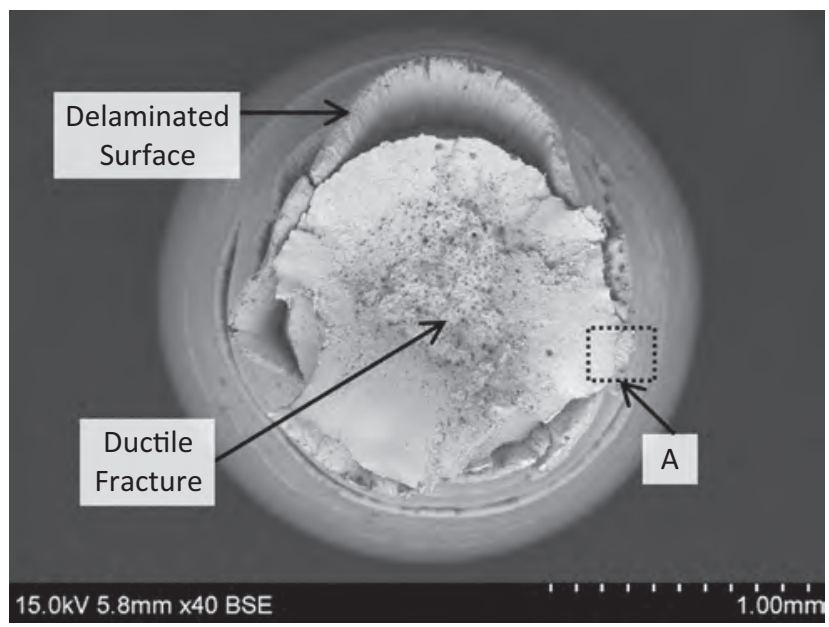

Fig. 16. Fracture surface of S32205 HE SSRT specimen in carbonated solution that was potentiostatically polarized to $-0.82 \mathrm{~V}$ vs. SCE.

In Fig. 17, there is a definite transition between the ductile fracture in the center of the specimen and the brittle cleavage fracture at the surface. This transition likely indicates that $\mathrm{H}$ has only partially diffused into the specimen. In this case, HE occurred to a

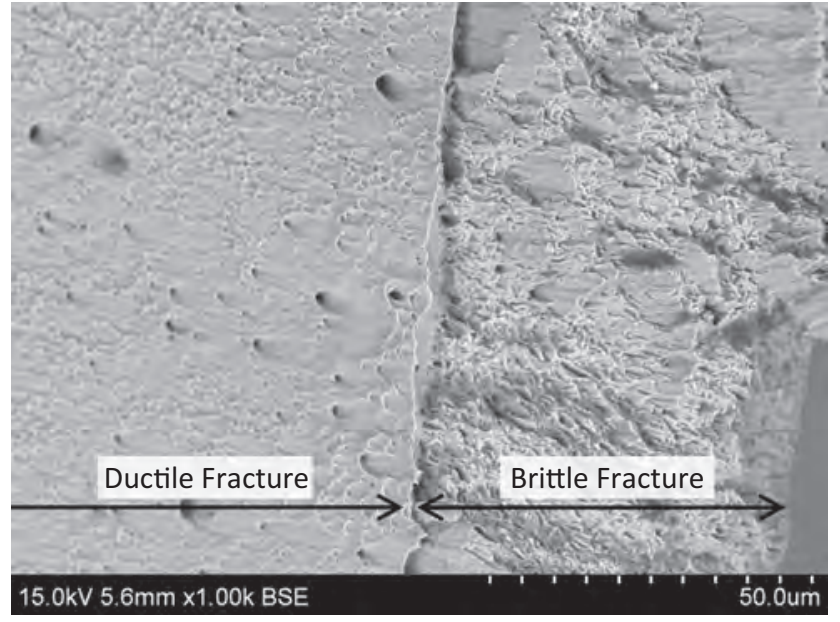

Fig. 17. Fracture surface of S32205 HE SSRT specimen in carbonated solution corresponding to region "A" in Fig. 16.

depth of approximately $60 \mu \mathrm{m}$ from the surface during the $50 \mathrm{hr}$ SSRT. This means that only $9.4 \%$ of the cross section of the specimen was affected by HE. Therefore, it can be anticipated that if cathodic overprotection that results in the generation of $\mathrm{H}_{2}$ occurs over extended periods of time in service, $\mathrm{H}$ may saturate the steel and promote fully brittle fracture of the cross section.

\section{Conclusions}

- Stranding reduced the corrosion resistance of S32304 specimens due to crevice corrosion. Grade S32205 strand specimens were still fully resistant to corrosion at $\mathrm{Cl}^{-}$concentrations up to $1.0 \mathrm{M}$ in alkaline and carbonated solutions. The superior corrosion resistance of S32205 is derived from its 3.2\% Mo content, which contributes to its corrosion resistance in the acidic conditions that develop within the crevice region of the strand during corrosion propagation.

- Slow strain rate testing (SSRT) of S32205 and S32304 high strength duplex stainless steels showed no damage by SCC at $\mathrm{Cl}^{-}$concentrations of $0.5 \mathrm{M}$ in alkaline and carbonated solutions. This conclusion is based on results from stress vs. time measurements during SSRTs and also forensic investigations of fracture surfaces following testing.

- Damage by HE was observed in S32205 and S32304 SSRT specimens. HE cracking was isolated to the necked region of SSRT specimens. Examination of the fracture surface showed that brittle fracture by HE had occurred only in the surface of the specimen, with the rest of the fracture being ductile. With longer periods of cathodic overprotection, it is likely that the damage due to HE would become more extensive and the mechanical behavior would be more brittle.

\section{Acknowledgements}

The authors thank the Georgia Department of Transportation (GDOT) for sponsoring this research under Project No. 07-70 and U.S. Army Environmental Quality and Installations Basic Research Program. Sumiden Wire Products Corporation and Fagersta Stainless are thanked for their donation of materials and all technical assistance provided. The authors would also like to thank Daniel 
Schuetz for assistance with the production of test specimens and metallographic sample preparation and Jamshad Mahmood for help with fabricating experimental setups. The opinions and conclusions expressed herein are those of the authors and do not represent the opinions, conclusions, policies, standards or specifications of the GDOT or of other cooperating organizations.

\section{References}

[1] M.F. Montemor, A.M.P. Simões, M.G.S. Ferreira, Chloride-induced corrosion on reinforcing steel: from the fundamentals to the monitoring techniques, Cem. Concr. Compos. 25 (2003) 491-502.

[2] R.D. Moser, R.B. Holland, L.F. Kahn, P.M. Singh, K.E. Kurtis, GDOT Technical Report: Durability of Precast Prestressed Concrete Piles in Marine Environments: Reinforcement Corrosion and Mitigation - Part 1, Georgia Institute of Technology, Atlanta, GA, 2010, p. 53.

[3] D. Addari, B. Elsener, A. Rossi, Electrochemistry and surface chemistry of stainless steels in alkaline media simulating concrete pore solutions, Electrochim. Acta 53 (2008) 8078-8086.

[4] S.M. Alvarez, A. Bautista, F. Velasco, Corrosion behaviour of corrugated lean duplex stainless steels in simulated concrete pore solutions, Corros. Sci. 53 (2011) 1748-1755.

[5] A. Bautista, G. Blanco, F. Velasco, A. Gutiérrez, L. Soriano, F.J. Palomares, et al., Changes in the passive layer of corrugated austenitic stainless steel of low nickel content due to exposure to simulated pore solutions, Corros. Sci. 51 (2009) 785-792.

[6] L. Bertolini, F. Bolzoni, T. Pastore, P. Pedeferri, Behaviour of stainless steel in simulated concrete pore solution, Br. Corros. J. 31 (1996) 218-222.

[7] G.G. Clemena, Investigation of the resistance of several new metallic reinforcing bars to chloride-induced corrosion in concrete, Virginia Trans. Res. Council (2003).

[8] M.C. García-Alonso, M.L. Escudero, J.M. Miranda, M.I. Vega, F. Capilla, M.J. Correia, et al., Corrosion behaviour of new stainless steel reinforcing bars embedded in concrete, Cem. Concr. Res. 37 (2007) 1463-1471.

[9] D.B. McDonald, M.R. Sherman, D.W. Pfeifer, Y.P. Virmani, Stainless steel reinforcing as corrosion protection, Concr. Int. (1995) 65-70.

[10] J.R. Scully, M.F. Hurley, Investigation of the corrosion propagation characteristics of new metallic reinforcing bars, Virginia Trans. Res. Council (2007) 63.

[11] W.H. Hartt, R.G. Powers, V. Leroux, D.K. Lysogorski, Critical Literature Review of High-Performance Corrosion Reinforcements in Concrete Bridge Applications, Florida Atlantic University, 2004, p. 53.

[12] W.H. Hartt, R.G. Powers, D.K. Lysogorski, V. Liroux, Y.P. Virmani, Corrosion Resistant Alloys for Reinforced Concrete, Florida Atlanta University, 2007, p. 135.

[13] E.G. Nawy, Prestressed Concrete - A Fundamental Approach, Prentice Hall, Upper Saddle River, NJ, 2000.

[14] E. Proverbio, L.M. Bonaccorsi, Failure of prestressing steel induced by crevice corrosion in prestressed concrete structures, 9th International Conference on Durability of Materials and Componentsin-house publishing, Rotterdam (Netherlands):, 2002, p. 7. p. appox.

[15] R.D. Moser, P.M. Singh, L.F. Kahn, K.E. Kurtis, Chloride-induced corrosion of prestressing steels considering crevice effects and surface imperfections, Corrosion 67 (6) (2011). 065001-1-065001-14.

[16] J. Mietz, B. Isecke, Assessment of test methods for evaluation stress corrosion cracking susceptibility of prestressing steels, Mater Corros 53 (2002) 373-384.

[17] Nürnberger U. Hydrogen Induced Cracking of Prestressing Steel in Concrete Constructions. EUROCORR. Nice, France2009.

[18] R.M. Schroeder, I.L. Müller, Stress corrosion cracking and hydrogen embrittlement susceptibility of an euctectoid steel employed in prestressed concrete, Corros Sci. 45 (2003) 1969-1983.

[19] M. Elices, L. Cabllero, A. Valiente, J. Ruiz, A. Martin, Hydrogen embrittlement of steel for prestressing concrete: the FIP and DIBt Tests, Corrosion 64 (2008) $164-174$.

[20] W.H. Hartt, C.C. Kumria, R.J. Kessler, Influence of potential, chlorides, pH, and precharging time on embrittlement of cathodically polarized prestressing steel, Corrosion 49 (1993) 377-385.

[21] J. Mietz, Investigations on hydrogen-induced embrittlement of quench and tempered prestressing steels, Mater. Corros. 51 (2000) 80-90.

[22] M. Schupack, M.G. Suarez, some recent corrosion embrittlement failures of prestressing systems in the united states, J PCI (1982) 38-55.
[23] J.F. Jenkins, Validation of nitronic 33 in reinforced and prestressed concrete, Naval Facilites Eng. Command (1987).

[24] M.C. Alonso, Corrosion Performance of High Strength Stainless Steel for Tendon Applications. Final Conference of COST Action 5342007 Toulouse, France.

[25] M.C. Alonso, F.J. Recio, Aceros Inoxidables De Alta Resitencia Mecanica En Medios Alcalinos con Cloruros. XXIV Encuentro del Grupo Nacional de Fractura. Burgos, Spain 2007.

[26] M. C. Alonso, F. J. Recio, M. Sanchez, High strength stainless steels for prestressed concrete structures in marine environment, in 1st Internationa Conferece Construction Heritage in Coastal and Marine Environments Damage, Diganosis, Maintenance and Rehabilitation. Lisbon, Portugal 2008.

[27] U. Nürnberger, High strength stainless steel - Alternative materials for tension members in Civil Engineering, Otto-Graf-J. 14 (2003) 45-66.

28] U. Nürnberger, Y. Wu, High-strength stainless steel in prestressed concrete, in: P. Swiatek (Ed.), Workshop of COST on NTD Assessment and New Systems in Prestressed Concrete Structures, Institute for Terotechnology, Kielce, Poland 2005, pp. 33-38.

[29] U. Nürnberger, Y, Wu, Stainless steel in concrete structures and in the fastening technique, Mater Corros 59 (2008) 144-158.

[30] Y. Wu, U. Nürnberger, Corrosion-technical properties of high-strength stainless steels for the application in prestressed concrete structures, Mater Corros. 60 (2009) 771-780.

[31] R.D. Moser, P.M. Singh, L.F. Kahn, K.E. Kurtis, Chloride-induced corrosion resistance of high-strength stainless steels in simulated alkaline and carbonated concrete pore solutions, Corros. Sci. 57 (2012) 241-253.

[32] M. Koyama, C.C. Tasan, E. Akiyama, K. Tsuzaki, D. Raabe, Hydrogen-assisted decohesion and localized plasticity in dual-phase steel, Acta Mater. 70 (2014) $174-187$.

[33] Heon-Young Ha, Tae-Ho Lee, Sangshik Kim, Effect of W on stress corrosion cracking susceptibility of newly developed Ni-saving duplex stainless steels, Met. Mater. Int. 23 (1) (2017) 115-125.

[34] R. Silverstein, D. Eliezer, Mechanisms of hydrogen trapping in austenitic duplex, and super martensitic stainless steels, J. Alloy. Compd. 720 (2017) 451-459.

[35] A.M. Elhoud, Neill Charles Renton, Wiliam F. Deans, Hydrogen embrittlement of super duplex stainless steel in acid solution, Int. J. Hydrogen Energy 35 (12) (2010) 6455-6464.

[36] B.R.S. Da Silva, F. Salvio, D.S. Dos Santos, Hydrogen induced stress cracking in UNS S32750 super duplex stainless steel tube weld joint, Int. J. Hydrogen Energy 40 (47) (2015) 17091-17101.

[37] S.S. Tavares, I.N. Bastos, J.M. Pardal, T.R. Montenegro, M.R. Da Silva, Slow strain rate tensile test results of new multiphase $17 \% \mathrm{Cr}$ stainless steel under hydrogen cathodic charging, Int. J. Hydrogen Energy 40 (47) (2015) $16992-$ 16999.

[38] H.Y. Ha, C.H. Lee, T.H. Lee, S. Kim, Effects of nitrogen and tensile direction on stress corrosion cracking susceptibility of Ni-free FeCrMnC-based duplex stainless steels, Materials 10 (3) (2017) 294.

[39] N. Kheradmand, R. Johnsen, J.S. Olsen, A. Barnoush, Effect of hydrogen on the hardness of different phases in super duplex stainless steel, Int. J. Hydrogen Energy 41 (1) (2016) 704-712.

[40] Q. Liu, Q. Zhou, J. Venezuela, M. Zhang, A. Atrens, The role of the microstructure on the influence of hydrogen of some advanced high-strength steels, Mater Sci. Eng. A 715 (2018) 370-378.

[41] F. Zanotto, V. Grassi, A. Balbo, C. Monticelli, F. Zucchi, Stress-corrosion cracking behaviour of lean-duplex stainless steels in chloride/thiosulphate environments, Metals 8 (4) (2018) 237.

[42] ASTM A276. ASTM A276 - 08 Standard Specification for Stainless Steel Bars and Shapes. In: American Society of Testing and Materials, editor. West Conshohocken, PA 2008.

43] ASTM G31. Standard Practice for Laboratory Immersion Corrosion Testing of Metals. West Conshohocken, PA: American Society of Testing and Materials; 2004.

[44] L. Li, A.A. Sagues, Chloride corrosion threshold of reinforcing steel in alkaline solutions - Cyclic polarization behavior, Corrosion 58 (2002) 305-316.

[45] G.M. Ugiansky, J.H. Payer, Stress Corrosion Cracking - The Slow Strain-Rate Technique, ASTM, Philadelphia, PA, 1977.

[46] D.A. Jones, Principles and Prevention of Corrosion, Prentice Hall, Upper Saddle River, NJ, 1996.

[47] A.J. Bard, L.R. Faulkner, Electrochemical Methods, John Wiley \& Sons, Inc. Hoboken, NJ, 2001.

[48] R. Merello, F.J. Botana, J. Botella, M.V. Matres, M. Marcos, Influence of chemica composition on the pitting corrosion resistance of non-standard low-Ni highMn-N duplex stainless steels, Corros. Sci. 45 (2003) 909-921.

[49] F. Presuel-Moreno, J.R. Scully, S.R. Sharp, Literature review of commercially available alloys that have potential as low-cost corrosion-resistant concrete reinforcement, Corrosion 68 (2010) 1-13. 


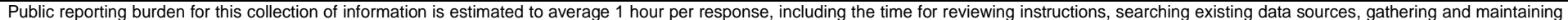

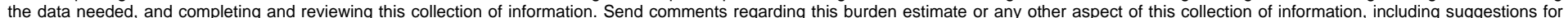

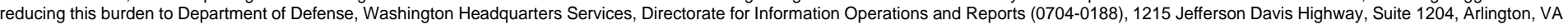

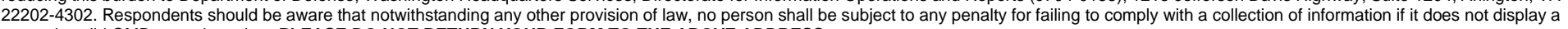
currently valid OMB control number. PLEASE DO NOT RETURN YOUR FORM TO THE ABOVE ADDRESS.
1. REPORT DATE (DD-MM-YYYY)
August 2021

4. TITLE AND SUBTITLE

Crevice Corrosion and Environmentally Assisted Cracking of High-Strength Duplex

Stainless Steels in Simulated Concrete Pore Solutions

\section{AUTHOR(S)}

Robert D. Moser, Preet M. Singh, Lawrence F. Kahn, Kimberly E. Kurtis, David González Niño, Zackery B. McClelland

\section{PERFORMING ORGANIZATION NAME(S) AND ADDRESS(ES)}

See next page.

\section{SPONSORING I MONITORING AGENCY NAME(S) AND ADDRESS(ES)}

U.S. Army Corps of Engineers

Washington, DC 20314

\section{DATES COVERED (From - To)}

5a. CONTRACT NUMBER

5b. GRANT NUMBER

5c. PROGRAM ELEMENT NUMBER

5d. PROJECT NUMBER

5e. TASK NUMBER

5f. WORK UNIT NUMBER

8. PERFORMING ORGANIZATION REPORT NUMBER

ERDC/GSL MP-21-3

10. SPONSOR/MONITOR'S ACRONYM(S)

11. SPONSOR/MONITOR'S REPORT NUMBER(S)

\section{DISTRIBUTION / AVAILABILITY STATEMENT}

Approved for public release; distribution is unlimited.

\section{SUPPLEMENTARY NOTES}

This article was originally published online in Construction and Building Materials on 25 January 2019.

This research was sponsored by the Georgia Department of Transportation (GDOT) under Project No. 07-70 and the U.S. Army Environmental Quality and Installations Basic Research Program.

\section{ABSTRACT}

This paper presents a study of crevice corrosion and environmentally assisted cracking (EAC) mechanisms in UNS S32205 and S32304 which were cold drawn to tensile strengths of approximately $1300 \mathrm{MPa}$. The study utilized a combination of electrochemical methods and slow strain rate testing to evaluate EAC susceptibility. UNS S32205 was not susceptible to crevice corrosion in stranded geometries at $\mathrm{Cl}^{-}$concentrations up to $1.0 \mathrm{M}$ in alkaline and carbonated simulated concrete pore solutions. UNS S32304 did exhibit a reduction in corrosion resistance when tested in a stranded geometry. UNS S32205 and S32304 were not susceptible to stress corrosion cracking at $\mathrm{Cl}^{-}$concentrations up to $0.5 \mathrm{M}$ in alkaline and carbonated solutions but were susceptible to hydrogen embrittlement with cathodic overprotection.

\section{SUBJECT TERMS}

Stainless steel, Concrete, Cyclic voltammetry, Crevice corrosion, Stress corrosion, Hydrogen embrittlement

\section{SECURITY CLASSIFICATION OF:}

\section{a. REPORT}

Unclassified

b. ABSTRACT
Unclassified

17. LIMITATION OF ABSTRACT

\section{c. THIS PAGE}

Unclassified
18. NUMBER OF PAGES

UU

19a. NAME OF RESPONSIBLE
PERSON
19b. TELEPHONE NUMBER (include
area code)




\section{PERFORMING ORGANIZATION NAME(S) AND ADDRESS(ES)}

Geotechnical and Structures Laboratory U.S. Army Engineer Research and Development Center 3909 Halls Ferry Road

Vicksburg, MS 39180

School of Materials Science \& Engineering /School of Civil \& Environmental Engineering Georgia Institute of Technology

North Ave NW

Atlanta, GA 30332

Department of Civil Engineering

University of Arkansas

Fayetteville, AR 72701 